\title{
Tracheal cuff pressure change before and after the performance of nursing care
}

Mudança de pressão do balonete traqueal antes e depois da realização dos cuidados de enfermagem Cambio de la presión del manguito traqueal antes y después de la realización de los cuidados de enfermería

\section{Lúcia Marinilza Beccaria', Thays Marley Antonio Doimo", Nádia Aparecida Antonia Polletti', Tais Pagliuco Barbosa", Daniele Cristiny da Silva", Alexandre Lins Werneck'}

' Fundação Faculdade de Medicina de São José do Rio Preto, Medical School. São José do Rio Preto, São Paulo, Brazil.

"Fundação Faculdade de Medicina de São José do Rio Preto, Base Hospital, Intensive Care Unit. São José do Rio Preto, São Paulo, Brazil.

\section{How to cite this article:}

Beccaria LM, Doimo TMA, Polletti NAA, Barbosa TP, Silva DC, Werneck AL. Tracheal cuff pressure change before and after the performance of nursing care. Rev Bras Enferm [Internet]. 2017;70(6):1145-50.

DOI: http://dx.doi.org/10.1590/0034-7167-2016-0486

Submission: 12-06-2016 Approval: 07-19-2017

\section{ABSTRACT}

Objective: Verify the changes of endotracheal cuff pressure before and after oral hygiene, head-of-bed elevation at $0^{\circ}, 30^{\circ}$, and $60^{\circ}$, change in body position, aspiration of the endotracheal tube, and in-bed bathing. Method: The study sample was composed of 88 patients. We performed 3,696 checks from July to September 2014. Results: Pressure values were analyzed in seven nursing care in the morning. Six of them were significantly altered before and after nursing procedure. In the afternoon, five of the health care provided were altered, and in the evening, only two. Most of pressure values were below recommended. Conclusion: There were differences before and after health care provided, showing changes in cuff pressure. In-bed bathing and head-of-bed elevation at $30^{\circ}$ were the ones that most altered pressure values in the three working shifts. Therefore, it is necessary to measure cuff pressure at least twice per working shift, preferably after bathing.

Descriptors: Intubation, Intratracheal; Pressure; Intensive Care Units; Nursing; Patient.

\section{RESUMO}

Objetivo: Verificar As mudanças de pressão do balonete traqueal antes e após higiene oral, elevação da cabeceira do leito a $0^{\circ}, 30^{\circ}$ e $60^{\circ}$, mudança de decúbito, aspiração traqueal e banho no leito. Método: A população foi composta por 88 pacientes, totalizando 3696 verificações de julho a setembro de 2014. Resultados: Os valores de pressão foram analisados em sete procedimentos de cuidados de enfermagem realizados na parte da manhã. Seis apresentaram estavam alterações significativas antes e após a realização dos procedimentos de enfermagem. No período da tarde, cinco dos procedimentos de cuidados de enfermagem realizados apresentaram alterações, e à noite, apenas dois. A maioria dos valores de pressão estava abaixo dos valores recomendados. Conclusão: Houve diferenças antes e após a realização dos cuidados, demonstrando alteração da pressão do balonete. O banho no leito e a elevação da cabeceira do leito a $30^{\circ}$ apresentou valores de pressão mais alterados nos três turnos de trabalho. Portanto, é necessário medir a pressão do balonete pelo menos duas vezes por turno de trabalho, de preferência após o banho.

Descritores: Intubação Endotraqueal; Pressão; Unidades de Terapia Intensiva; Enfermagem; Paciente.

\section{RESUMEN}

Objetivo: verificar los câmbios de presión del manguito traqueal antes y después de la higiene oral, elevación de la cabecera del lecho a $0^{\circ}, 30^{\circ}$ y $60^{\circ}$, cambio de decúbito, aspiración traqueal y baño en el lecho. Método: La población fue compuesta por 88 pacientes, totalizando 3696 verificaciones de julio a septiembre de 2014. Resultados: Los valores de presión fueron analisados em siete procedimentos de atención de enfermeira realizados em la parte de la mañana. Seis apresentaron alteraciones significativas antes y después de la realización de los procedimentos de enfermería. En el periodo de la tarde, cinco de los procedimentos de atención de enfermería realizados apresentaron alteraciones, y por la noche, sólo dos. Conclusión: Hubo diferencias antes y después de la 
realización de la atención de enfermería, demostrando alteración de la presión del manguito. El baño em el lecho y la elevación de la cabecera del lecho a $30^{\circ}$ presentó valores de presíon más alterados em los tres turnos de trabajo, preferentemente después del baño. Descriptores: Intubación Endotraqueal; Presión; Unidades de Terapia Intensiva; Enfermería; Paciente.

\section{CORRESPNDING AUTHOR Lúcia Marinilza Beccaria Email: lucia@famerp.br}

\section{INTRODUCTION}

Tracheal intubation with a cuffed tube is considered definitive airway management in adults. The tube cuff is designed to provide a seal against aspiration and to prevent leaks during positive pressure ventilation ${ }^{(1-3)}$. Hemodynamic instability, hypoxemia and acidosis in ICU patients indicate the need for maintaining a secure airway for these patients ${ }^{(3)}$. In mechanically ventilated patients, the endotracheal tube cuff should remain inflated in order to prevent gas leakage and aspiration of oropharyngeal contents into the lungs ${ }^{(4)}$. Clinical complications range from a mild sore throat to tracheoesophageal fistula, tracheocarotid artery erosion, tracheal stenosis, and even tracheal rupture ${ }^{(1)}$.

Poor physical conditions, emergent intubation, and medication in ICU bring the high risk of intubation complications as high as $54 \%{ }^{(3)}$. Sore throat, dysphagia, and/or dysphonia are reported in approximately $50 \%$ of cases. Cough can be more problematic, leading to hemodynamic alterations, arrhythmias, increase in intraocular and intracranial pressures, bronchospasm, and postoperative surgical complications. According to the literature, the incidence of cough at emergence ranges from 40 to $96 \%{ }^{(5)}$.

The development of increasingly more sophisticated ventilators allow for fine adjustment of sensitivity and include several trigger mechanisms, different inspiratory flow speeds, acceleration, mechanisms for ending inspiratory time, and monitoring options, which enable adjustment of the patient-ventilator synchrony and MV as a function of the patient's disease. In this regard, the possibility of providing differential ventilatory support for restrictive and obstructive conditions stands out ${ }^{(6)}$.

Different methods have been proposed to decrease the adverse effects associated with mucosal irritation caused by the endotracheal tube (ETT), including the administration of opioids, extubation under deep anesthesia, use of fluticasone, and injection of intravenous lidocaine ${ }^{(5)}$. On the other hand, high incidence of tracheal mucosal lesions is attributed to high cuff pressure compres$\operatorname{sion}^{(3)}$. Hyperinfation of the endotracheal cuff to pressures more than $25 \mathrm{~cm} \mathrm{H} 2 \mathrm{O}$ or greater is contributed to mucosal ischemia and subsequent destruction of the tracheal wall(7).

The pressure exerted on the trachea must be maintained within a therapeutic range $\left(25-30 \mathrm{cmH}_{2} \mathrm{O}\right.$ or $18-22 \mathrm{mmHg}$ ) that is high enough to ensure delivery of mechanical ventilation and prevention of marked aspiration, but low enough to ensure perfusion to the tracheal capillaries without causing injury ${ }^{(2,8)}$. The most common cause of non-malignant tracheoesophageal fistula remains cuff-related tracheal injury. Laryngeal stenosis is the most serious long-term complication of tracheal intubation in children due to scarring of the ulcerated mucosa ${ }^{(1)}$.

Nowadays endotracheal tubes have highvolume lowpressure cuffs, generally made of polyvinylchloride or polyurethane. Cuff pressure is essential in endotracheal tube management. The tubes facilitate positive-pressure ventilation and reduce aspiration of subglottic secretions ${ }^{(9)}$. Several interventions have been used to reduce the cuff pressure and decrease the incidence of associated adverse consequences. Providing the stable cuff pressure by filling the cuffs with anesthetic gas mixture control of cuff pressure was effective in minimizing the incidence and severity of tracheal mucosal damage ${ }^{(3)}$. Tracheal mucosal blood flow is impaired when the tracheal cuff pressure is above $30 \mathrm{~cm}$ of water, which may lead to ischemia ulceration ${ }^{(1)}$.

Cuff pressure can be measured with a simple and cheap anaeroid manometer that does not require maintenance. It is quick and easy to use and excessive pressures can be adjusted immediately. A cuff pressure between 20 and $30 \mathrm{~cm}$ of water has been proposed guideline published by the Royal College of Anaesthetists ${ }^{(10)}$. Apart from maintaining correct cuff pressure, it is important to perform cuff pressure measurements at 6 - 12-hourly intervals and to use the correct method ${ }^{(2)}$.

This study is relevant because there is no ideal pressure volume related to anatomical differences in patients. The ideal volume is that one, which the cuff allows ventilation with positive pressure without air leakage. The extent, if any, that cuff shape influences cuff pressure after changes in body position is unknown. The object of this study was to verify whether there has been a change in cuff pressures before and after the nursing care.

\section{OBJECTIVE}

Verify the changes of endotracheal cuff pressure before and after oral hygiene, head-of-bed elevation at $0^{\circ}, 30^{\circ}$, and $60^{\circ}$, change in body position, aspiration of the endotracheal tube, and in-bed bathing.

\section{METHOD}

\section{Ethical aspects}

The study meets the Resolution 466/2012, considering researches involving human beings, received approval of the Research Ethics Committee.

\section{Design, study local, period}

This is a prospective, retrospective, and cross-sectional study. The study was carried out in four intensive care units (ICU) of a teaching hospital in the Northwest region of São Paulo State. The participant facilities were the ICU prepaid health plan, the ICU from the Unified Health System (SUS), the emergency ICU, and the cardiology ICU. The study sample consisted of 88 patients comprising 3,696 checks and it was carried out from July to September 2014.

\section{Study population/sampling}

In order to determine the study sample, we used the intentional non-probabilistic sampling technique. The inclusion criteria were adult patients intubated via endotracheal or nasotracheal under 
mechanical ventilation using a tube with high-volume low-pressure cuff and a diameter ranging from 7.0 to 8.5 $\mathrm{cm}$. Exclusion criteria were patients in whom the decubitus changes were contraindicated; inadequate integrity of the external cuff, favoring a false positive result, and patients with tracheostomy tube.

\section{Study protocol}

Cuff pressure was measured using a manometer or a cufflator (VBM Cuff Pressure Gauge) with an integrated pressure monitor, which indicates the optimal range of pressure; a pressure calibration pump with a release/ bleed valve; an analog cuff pressure gauge and inflator for tracheal tubes, ranging from 0 to $120 \mathrm{~cm} \mathrm{H}_{2} \mathrm{O}$ with color ranges on the scale for optimum pressure readings, and an inflator bulb to adjust the proper pressure with a release valve.

The pressure checking was recorded on a checklist prepared by the authors containing variables such as gender, age, and lumen diameter. Nursing care included in-bed bathing, oral hygiene, suction tube, or cannula, patients' head-of-bed elevation at $0^{\circ}, 30^{\circ}$, and $60^{\circ}$, and change of positioning of patients in bed. We also verified whether this change occurred independently of the tracheal intubation time. Nurses who carried out the research and worked at the facilities performed records every 8 hours.

All selected patients were initially placed in the 35 degrees semi-Fowler position (the Semi-Fowler position is the position of a patient who is lying in bed in a supine position with the head-of-bed at approximately 30 to 45 degrees). At first, it was verified and recorded the cuff internal pressure. Then, it was adjusted to $25 \mathrm{cmH}_{2} \mathrm{O}$ before the beginning of nursing procedures. This parameter was suggested by the Brazilian recommendations of mechanical ventilation $2013^{(9)}$ Just after the procedure is accomplished, all the parameters were rechecked and corrected when necessary, which occurred consecutively in three times (day, evening, and night).

\section{Results and statistical analyses}

Data are expressed as percentage, mean \pm standard deviation or median (range) as appropriate. Proportions were compared before and after intervention. The comparison of average results was made by the Wilcoxon test $(p \leq 0.05)$. Data were analyzed using paired nonparametric statistical methods. The statistical software Prism 6.0 was used for all tests.

\section{RESULTS}

The study sample was composed of 88 patients. We performed 3,696 checks from July to September 2014 at the four ICU facilities. Patients' age ranged from 56 to 60 years and from 71 to 75 years, $10 \%$ e $11 \%$, respectively, and $58 \%$ were male.
Table 1 - Cuff pressure: mean \pm standard deviation and median referring to morning shift, São José do Rio Preto, São Paulo, Brazil, 2016

\begin{tabular}{|c|c|c|c|c|}
\hline Nursing care & Mean & SD & Median & $p$ value \\
\hline $\begin{array}{l}\text { Before bathing } \\
\text { After bathing }\end{array}$ & $\begin{array}{l}29.32 \\
19.37\end{array}$ & $\begin{array}{l}19.06 \\
4.16\end{array}$ & $\begin{array}{l}20 \\
20\end{array}$ & $<0.0001^{*}$ \\
\hline $\begin{array}{l}\text { Before oral hygiene } \\
\text { After oral hygiene }\end{array}$ & $\begin{array}{l}20.05 \\
20.42\end{array}$ & $\begin{array}{l}7.64 \\
4.19\end{array}$ & $\begin{array}{l}20 \\
20\end{array}$ & $0.0482 *$ \\
\hline $\begin{array}{l}\text { Before aspiration of endotracheal tube } \\
\text { After aspiration of endotracheal tube }\end{array}$ & $\begin{array}{l}20.35 \\
19.32\end{array}$ & $\begin{array}{l}3.93 \\
3.61\end{array}$ & $\begin{array}{c}20 \\
9\end{array}$ & $0.0075^{*}$ \\
\hline $\begin{array}{l}\text { Before head-of-bed elevation at } 0^{\circ} \\
\text { After head-of-bed elevation at } 0^{\circ}\end{array}$ & $\begin{array}{l}20.53 \\
18.72\end{array}$ & $\begin{array}{l}8.14 \\
3.40\end{array}$ & $\begin{array}{c}19 \\
18.5\end{array}$ & $0.0489 *$ \\
\hline $\begin{array}{l}\text { Before head-of-bed elevation at } 30^{\circ} \\
\text { After head-of-bed elevation at } 30^{\circ}\end{array}$ & $\begin{array}{l}19.00 \\
18.19\end{array}$ & $\begin{array}{l}3.58 \\
3.62\end{array}$ & $\begin{array}{l}19 \\
18\end{array}$ & $0.0039 *$ \\
\hline $\begin{array}{l}\text { Before head-of-bed elevation at } 60^{\circ} \\
\text { After head-of-bed elevation at } 60^{\circ}\end{array}$ & $\begin{array}{l}18.02 \\
19.29\end{array}$ & $\begin{array}{l}3.68 \\
4.33\end{array}$ & $\begin{array}{l}18 \\
17\end{array}$ & $0.9906^{*}$ \\
\hline $\begin{array}{l}\text { Before change of decubitus } \\
\text { After change of decubitus }\end{array}$ & $\begin{array}{l}18.31 \\
16.53\end{array}$ & $\begin{array}{c}34.37 \\
3.96\end{array}$ & $\begin{array}{l}17 \\
16\end{array}$ & $0.0005^{*}$ \\
\hline
\end{tabular}

Note: ${ }^{*} p$ values $\leq 0.05$ significant generated by the Wilcoxon test; $S D=$ Standard deviation.

Table 2 - Cuff pressure: mean \pm standard deviation and median referring to the night shift, São José do Rio Preto, São Paulo, Brazil, 2016

\begin{tabular}{lccccc}
\hline Nursing care & Mean & SD & Median & $\boldsymbol{p}$ value \\
\hline Before bathing & 24.89 & 13.83 & 20 & \\
After bathing & 19.77 & 6.21 & 20 & $0.0005^{*}$ \\
Before oral hygiene & 19.79 & 6.05 & 20 & \\
After oral hygiene & 19.92 & 3.64 & 20 & 0.145 \\
Before aspiration of endotracheal tube & 25.91 & 17.28 & 21 & $0.0033^{*}$ \\
After aspiration of endotracheal tube $^{20.19}$ & 4.32 & 20 & \\
Before head-of-bed elevation at $0^{\circ}$ & 26.21 & 18.25 & 20 & \\
After head-of-bed elevation at $0^{\circ}$ & 21.20 & 6.50 & 20 & $0.0019^{*}$ \\
Before head-of-bed elevation at $30^{\circ}$ & 21.22 & 6.57 & 20 & \multirow{2}{*}{$\mathbf{0 . 0 0 0 1 *}$} \\
After head-of-bed elevation at $30^{\circ}$ & 18.96 & 4.63 & 18 & \\
Before head-of-bed elevation at $60^{\circ}$ & 19.01 & 4.65 & 18 & \multirow{2}{*}{0.2396} \\
${\text { After head-of-bed elevation at } 60^{\circ}}^{18.48}$ & 4.45 & 19 & \\
Before change of decubitus & 18.40 & 4.32 & 19 & \multirow{2}{*}{$0.0013^{*}$} \\
After change of decubitus & 17.26 & 4.47 & 17 & \\
\hline
\end{tabular}

Note: ${ }^{*} p$ values $\leq 0.05$ significant generated by the Wilcoxon test; $S D=$ Standard deviation

Table 3 - Cuff pressure: mean \pm standard deviation and median referring to the night shift, São José do Rio Preto, São Paulo, Brazil, 2015

\begin{tabular}{lccccc}
\hline Nursing care & Mean & SD & Median & $\boldsymbol{p}$ value \\
\hline Before bathing & 30.63 & 22.07 & 23 & \multirow{2}{*0.0001*}{} \\
After bathing & 18.50 & 3.61 & 18 & \\
Before oral hygiene & 18.62 & 4.24 & 18 & \multirow{2}{*}{0.2214} \\
After oral hygiene & 19.07 & 4.08 & 20 & \\
Before aspiration of endotracheal tube & 19.20 & 4.06 & 20 & \multirow{2}{*}{0.0663} \\
After aspiration of endotracheal tube & 18.88 & 3.74 & 19 & \\
Before head-of-bed elevation at $0^{\circ}$ & 18.82 & 3.83 & 19 & \multirow{2}{*}{0.1462} \\
After head-of-bed elevation at $0^{\circ}$ & 18.27 & 3.71 & 18 & \\
Before head-of-bed elevation at $30^{\circ}$ & 18.46 & 4.06 & 18 & $0.0309^{*}$ \\
After head-of-bed elevation at $30^{\circ}$ & 17.80 & 3.76 & 18 & \\
Before head-of-bed elevation at $60^{\circ}$ & 17.82 & 3.81 & 18 & \multirow{2}{*}{0.3404} \\
After head-of-bed elevation at $60^{\circ}$ & 17.55 & 3.42 & 18 & \\
Before change of decubitus & 17.59 & 3.38 & 18 & \multirow{2}{*}{0.2189} \\
After change of decubitus & 17.02 & 3.37 & 17 & \\
\hline
\end{tabular}

Note: ${ }^{*} p$ values $\leq 0.05$ significant generated by the Wilcoxon test; $S D=$ Standard deviation. 
Table 1 shows tracheal cuff pressure values in the morning. Table 2 shows tracheal cuff pressure values at the afternoon shift. Table 3 shows tracheal cuff pressures at the night shift.

Table 4 - Cuff pressure: average summation comparing the three shifts, São José do Rio Preto, São Paulo, Brazil, 2016

\begin{tabular}{|c|c|c|c|}
\hline \multirow{2}{*}{ Nursing care } & \multicolumn{3}{|c|}{$\begin{array}{c}\text { Cuff pressure }<25 \mathrm{cmH}_{2} \mathrm{O}: \\
\text { average summation }\end{array}$} \\
\hline & $\underset{(\%)}{\operatorname{Morning}}$ & $\begin{array}{l}\text { Afternoon } \\
(\%)\end{array}$ & $\begin{array}{c}\text { Night } \\
(\%)\end{array}$ \\
\hline $\begin{array}{l}\text { Before bathing } \\
\text { After bathing }\end{array}$ & $\begin{array}{l}56.8 \\
89.8\end{array}$ & $\begin{array}{l}68.2 \\
86.4\end{array}$ & $\begin{array}{l}53.4 \\
96.6\end{array}$ \\
\hline $\begin{array}{l}\text { Before oral hygiene } \\
\text { After oral hygiene }\end{array}$ & $\begin{array}{l}88.6 \\
75.0\end{array}$ & $\begin{array}{l}87.5 \\
84.1\end{array}$ & $\begin{array}{l}96.6 \\
87.5\end{array}$ \\
\hline $\begin{array}{l}\text { Before aspiration of endotracheal tube } \\
\text { After aspiration of endotracheal tube }\end{array}$ & $\begin{array}{l}73.9 \\
84.1\end{array}$ & $\begin{array}{l}73.9 \\
80.7\end{array}$ & $\begin{array}{l}85.2 \\
90.9\end{array}$ \\
\hline $\begin{array}{l}\text { Before head-of-bed elevation at } 0^{\circ} \\
\text { After head-of-bed elevation at } 0^{\circ}\end{array}$ & $\begin{array}{l}84.1 \\
96.6\end{array}$ & $\begin{array}{l}68.2 \\
75.0\end{array}$ & $\begin{array}{l}90.9 \\
95.5\end{array}$ \\
\hline $\begin{array}{l}\text { Before head-of-bed elevation at } 30^{\circ} \\
\text { After head-of-bed elevation at } 30^{\circ}\end{array}$ & 93.2 & $\begin{array}{l}73.9 \\
89.8\end{array}$ & $\begin{array}{l}92.0 \\
96.6\end{array}$ \\
\hline $\begin{array}{l}\text { Before head-of-bed elevation at } 60^{\circ} \\
\text { After head-of-bed elevation at } 60^{\circ}\end{array}$ & $\begin{array}{l}95.5 \\
90.9\end{array}$ & $\begin{array}{l}88.6 \\
90.9\end{array}$ & $\begin{array}{l}95.5 \\
97.7\end{array}$ \\
\hline $\begin{array}{l}\text { Before change of decubitus } \\
\text { After change of decubitus }\end{array}$ & $\begin{array}{l}89.8 \\
95.5\end{array}$ & $\begin{array}{l}92.0 \\
93.2\end{array}$ & $\begin{array}{c}98.9 \\
100.0\end{array}$ \\
\hline
\end{tabular}

\begin{tabular}{lccc} 
& \multicolumn{3}{c}{ average summation } \\
\cline { 2 - 4 } Nursing care & $\begin{array}{c}\text { Morning } \\
\mathbf{( \% )}\end{array}$ & $\begin{array}{c}\text { Afternoon } \\
\mathbf{( \% )}\end{array}$ & $\begin{array}{c}\text { Night } \\
\mathbf{( \% )}\end{array}$ \\
\hline Before bathing & 21.6 & 17.0 & 22.7 \\
After bathing & 9.1 & 12.5 & 1.1 \\
Before oral hygiene & 9.1 & 11.4 & 2,3 \\
After oral hygiene & 23.9 & 15.9 & 0.0 \\
Before aspiration of endotracheal tube & 26.1 & 18.2 & 0.0 \\
After aspiration of endotracheal tube & 15.9 & 17.0 & 0.0 \\
Before head-of-bed elevation at $0^{\circ}$ & 12.5 & 15.9 & 0.0 \\
After head-of-bed elevation at $0^{\circ}$ & 3.4 & 17.0 & 0.0 \\
Before head-of-bed elevation at $30^{\circ}$ & 6.8 & 18.2 & 0.0 \\
After head-of-bed elevation at $30^{\circ}$ & 4.5 & 8.0 & 1.1 \\
Before head-of-bed elevation at $60^{\circ}$ & 4.5 & 9.1 & 1.1 \\
After head-of-bed elevation at $60^{\circ}$ & 9.1 & 9.1 & 0.0 \\
Before change of decubitus & 10.2 & 8.0 & 0.0 \\
After change of decubitus & 4.5 & 5.7 & 0.0 \\
\hline
\end{tabular}

\begin{tabular}{lccc} 
& \multicolumn{3}{c}{$\begin{array}{c}\text { Cuff pressure }>\mathbf{3 0} \mathbf{~ c m ~}_{2} \mathbf{O} \text { : } \\
\text { average summation }\end{array}$} \\
\cline { 2 - 4 } & $\begin{array}{c}\text { Morning } \\
\mathbf{( \% )}\end{array}$ & $\begin{array}{c}\text { Afternoon } \\
\mathbf{( \% )}\end{array}$ & $\begin{array}{c}\text { Night } \\
(\mathbf{\%})\end{array}$ \\
\hline Before bathing & 21.6 & 1.1 & 22.7 \\
After bathing & 1.1 & 1.1 & 1.1 \\
Before oral hygiene & 2.3 & 1.1 & 2.3 \\
After oral hygiene & 1.1 & 0.0 & 0.0 \\
Before aspiration of endotracheal tube & 0.0 & 8.0 & 0.0 \\
After aspiration of endotracheal tube & 0.0 & 2.3 & 0.0 \\
Before head-of-bed elevation at $0^{\circ}$ & 3.4 & 15.9 & 0.0 \\
After head-of-bed elevation at $0^{\circ}$ & 0.0 & 8.0 & 0.0 \\
Before head-of-bed elevation at $30^{\circ}$ & 0.0 & 8.0 & 0.0 \\
After head-of-bed elevation at $30^{\circ}$ & 0.0 & 2.3 & 1.1 \\
Before head-of-bed elevation at $60^{\circ}$ & 0.0 & 2.3 & 1.1 \\
After head-of-bed elevation at $60^{\circ}$ & 0.0 & 0.0 & 0.0 \\
Before change of decubitus & 0.0 & 0.0 & 0.0 \\
After change of decubitus & 0.0 & 1.1 & 0.0 \\
\hline
\end{tabular}

Table 4 shows cuff pressure within normal parameters and when the values were higher and lower than that recommend in the three shifts (morning, afternoon and night).

\section{DISCUSSION}

The correct endotracheal cuff pressure must be less than the capillary perfusion pressure, i.e., less than $30 \mathrm{cmH}_{2} \mathrm{O}$. The ideal pressure is between 18 to $22 \mathrm{mmHg}$ and 25 to $30 \mathrm{~cm} \mathrm{H} 2 \mathrm{O}$ to prevent exhaust air or overinflation. The consensus establishes as an ideal practice to check cuff pressure daily and maintain it between 20 to $34 \mathrm{cmH}_{2} \mathrm{O}$ (15 to $\left.25 \mathrm{mmHg}\right)^{(11)}$. Postoperative dysphagia occurs frequently after anterior cervical spine surgery. This may be related to high endotracheal tube cuff pressure. Whether adaptation and maintaining the pressure after placement of the retractor will decrease the incidence of dysphagia, has to be determined by this trial ${ }^{(12)}$. Previous studies have shown that maintaining ETT cuff pressure between 15 and $25 \mathrm{~mm} \mathrm{Hg}$ can reduce endotracheal intubation-related complications in patients undergoing general anesthesia ${ }^{(13-14)}$.

In the present study, in the morning shift, when the nurses changed the angle of the head-of-bed elevation to $0^{\circ}, 30^{\circ}$, and $60^{\circ}$, it was observed a decrease from $20.53 \mathrm{mmHg}$ to $18.76 \mathrm{mmHg}$; from $19,00 \mathrm{mmHg}$ to $18,19 \mathrm{mmHg}$, and from $18.02 \mathrm{mmHg}$ to $18.29 \mathrm{mmHg}$, respectively. The statistically significant decrease occurred in $0^{\circ}$ and $30^{\circ}$ (6).

Regarding the change of body positioning (decubitus), there was a significant change in the cuff pressure in the morning shifts. The decrease in pressure ranged from $18.31 \mathrm{~mm} \mathrm{Hg}$ to $16.53 \mathrm{~mm} \mathrm{Hg}$. Of the 88 checks performed, $95.45 \%$ were below $25 \mathrm{cmH}_{2} \mathrm{O}$, and $4.54 \%$ between 25 to $30 \mathrm{~cm} \mathrm{H}_{2} \mathrm{O}$. In the evening shift, the average change ranged from $18.40 \mathrm{mmHg}$ to $17.26 \mathrm{mmHg}$. Of the 88 lower pressure checks, $93.18 \%$ were lower than $25 \mathrm{~cm} \mathrm{H} \mathrm{H}_{2} ; 1.13 \%$ above $30 \mathrm{cmH}_{2} \mathrm{O}$, and $5.68 \%$ within the desirable parameters, i.e., from 25 to 30 $\mathrm{cmH}_{2} \mathrm{O}$. Inflation of the cuff in excess of $30 \mathrm{~cm} \mathrm{H} 2 \mathrm{O}$ damages the tracheal mucosa by compromising capillary perfusion. When pressures are greater than $50 \mathrm{~cm} \mathrm{H} 2 \mathrm{O}$, total obstruction of tracheal blood flow occurs ${ }^{(9)}$.

Regarding nursing care, the in-bed bathing presented a significant change the endotracheal cuff pressure in the three shifts (morning, evening, and night) with mean cuff pressure ranging from $29.32 \mathrm{mmHg}$ to $19.37 \mathrm{mmHg}$; from 24.89 $\mathrm{mmHg}$ to $19.77 \mathrm{mmHg}$, and from $30.63 \mathrm{mmHg}$ to 18.50 $\mathrm{mmHg}$, respectively. It was not possible to find in the literature, studies showing relation with in-bed bathing, which requires further studies.

In the morning shift only, the oral hygiene showed a change in the endotracheal cuff pressure statistically significant, with a mean cuff pressure ranging from $20.05 \mathrm{mmHg}$ to 20.42 $\mathrm{mmHg}$. Among all nursing care analyzed, this was the one which less influenced in changing the cuff pressure.

We were no able to find data that could prove whether there is a change in the cuff pressure associated with oral hygiene. We have found the need to check the endotracheal cuff pressure prior to performing oral hygiene care as a way to prevent pneumonia associated with mechanical ventilation. The oral 
hygiene care is necessary to reduce plaque formation and accumulation of waste in the oropharynx, preventing the emergence of pathogenic micro-organisms and thus to migration of lower airways and possibly respiratory complications ${ }^{(15)}$.

In the aspiration of the endotracheal tube, there was a significant difference in pressure cuffs before and after measuring the aspiration in the morning shift, with a mean between the pressures ranging from $20.35 \mathrm{cmH}_{2} \mathrm{O}$ to $19.32 \mathrm{cmH}_{2} \mathrm{O}$. In the evening shift, we observed a difference ranging from 25.01 $\mathrm{cm} \mathrm{H}_{2} \mathrm{O}$ to $20.19 \mathrm{~cm} \mathrm{H}_{2} \mathrm{O}$. When comparing the morning, evening, and night shifts, we observed that $86.4 \%$ of the measurements in the morning shift were lower than $25 \mathrm{~cm} \mathrm{H} 2 \mathrm{O}$; in the evening shift, $82.3 \%$ were lower than $25 \mathrm{~cm} \mathrm{H} 2 \mathrm{O}$; and in the evening shift, $91.2 \%$ presented pressure cuff lower than $25 \mathrm{~cm} \mathrm{H} 2 \mathrm{O}$, i.e., changes presenting lower pressures relating to the adequate threshold pressure. The night shift presented the largest number of changes compared to the other shifts.

However, by analyzing the three shifts in a stratified way, the morning and evening shifts showed higher statistically significant difference in pressure cuffs when we performed measures before and after the nursing care. The nursing care performed were in the morning shift: in-bed bathing, oral hygiene, suction of endotracheal tube, head-of-bed elevation at $0^{\circ}$, head-of-bed elevation at $30^{\circ}$, and changes in body position. In the afternoon, the nursing care delivered was in-bed bathing, suction of endotracheal tube, head-of-bed elevation at $30^{\circ}$, and changes in body position. The only difference among the night shift and the other two shifts was in in-bed bathing and in head-of-bed elevation at $30^{\circ}$.

One study showed that high pressures were found in the three shifts. However, in the morning shift they had a mean of the values of the pressure cuffs of $36.7 \mathrm{cmH}_{2} \mathrm{O}$. The same was seen in another study, in which the cuff pressure measurements above $30 \mathrm{cmH}_{2} \mathrm{O}$ were found in the three shifts. Nevertheless, the night shift presented more cases of changes in the pressure cuff when compared with the other shifts, which presented $14 \%$ of cases $^{(16)}$.

Inflation of the cuff in excess of $30 \mathrm{~cm} \mathrm{H}_{2} \mathrm{O}$ damages the tracheal mucosa by compromising capillary perfusion. When pressures are greater than $50 \mathrm{~cm} \mathrm{H} 2 \mathrm{O}$, total obstruction of tracheal blood flow occurs ${ }^{(12)}$. Check the pressure of the cuff endotracheal tubes through a cuff meter three times a day is important because the greater the number of checks, the greater the chance to adjust the values. However, during the measurements may occur an air leak in the uncoupling; another role meant of cuff deflation is the air that is necessary to pressurize the device, showing a value less than the pre-existing one.

Maintaining the cuff pressure ranging from 18 to $22 \mathrm{mmHg}$ reduces the risk of a possible injury to the trachea. However, even if you reached the ideal pressure, but keeping it constantly for a time above 12 hours, there may be an inflammatory process in place. Therefore, possible complications are also related to the duration of the intubation. Our data indicate that cuff pressure should be measured after each change in a patient's body position and supports use of continuous monitoring of cuff pressure with automatic adaptation to a preset pressure.
Despite the obvious risks associated with excessive pressure on the tracheal wall, in daily practice, clinicians rarely evaluate cuff pressure to be sure it is correct. Indeed, cuff pressures outside the target range are common, and the frequency with which cuff pressure is measured and adjusted varies from never to at most every 8 hours ${ }^{(5)}$. Monitoring cuff pressure via a manometer results in fewer complications after intubation $^{(14)}$. The extent, if any, that cuff shape influences cuff pressure after changes in body position is unknown ${ }^{(5)}$.

Other study results suggest that changing patient position during mechanical ventilation can lead to significant alterations in Pcuff. This study concludes that various factors can induce lesions in the respiratory tract of mechanically ventilated patients. Such factors include the following: inadequate airway humidification; a high fraction of inspired oxygen; insufficient heating of administered gases; frequent tracheal suction; prolonged endotracheal intubation; prolonged mechanical ventilation; and inappropriate Pcuff values ${ }^{(4)}$. Cuff pressures $>30 \mathrm{cmH}_{2} \mathrm{O}$ compress mucosal capillaries, impair blood flow, cause mucosal damage and tracheal rupture, with total occlusion occurring at $50 \mathrm{cmH}_{2} \mathrm{O}^{(2)}$.

Changes in a patient's body position resulted in significant deviations in the cuff pressure of endotracheal tubes. In $40.6 \%$ of the measurements, the cuff pressure exceeded the upper target level, and thus theoretically was clinically relevant. Because simple and frequent changes in a patient's body position may result in potentially harmful cuff pressure, our observations suggest a need for a strict monitoring of this pressure ${ }^{(5)}$.

\section{Study limitation and contribution to Nursing}

The patients' anatomical differences were not related to the diameter and pressure inside the endotracheal tubes. Another limitation is concerning to the random allocation and findings, which were based on a single institution, which compromises data extrapolation.

The study intends to allow greater security in the delivery of health care to the intubated patient, as for the optimal pressure volume, thus, preventing accidental extubation and reducing the necrosis of the trachea.

\section{CONCLUSION}

There were differences before and after health care provided, showing changes in cuff pressure. In-bed bathing and head-of-bed elevation at $30^{\circ}$ were the ones that most altered pressure values in the three working shifts. Therefore, it is necessary to measure cuff pressure at least twice per working shift, preferably after bathing.

There were considerable differences before and after the nursing care provided, showing changes in cuff pressure. In-bed bathing and the head-of-bed elevation at $30^{\circ}$ were the most significant health care provided in all three working shifts. In-bed bathing and head-of-bed elevation at $30^{\circ}$ were the health care that most affected the pressures in all three working shifts Therefore, we suggest the measurement of cuff pressure at least twice every work shift, preferably after in-bed bathing, in order to prevent tracheal injury and accidental extubation. 


\section{REFERENCES}

1. Chopra M, Jones L, Boulanger C, Benger J, Higginson I, Williamson D, et al. Prospective observational measurement of tracheal tube cuff pressures in the emergency department. Emerg Med J [Internet]. 2010 [cited 2016 Jun 30];27(4):270-1. Available from: https://www.ncbi.nlm.nih.gov/pubmed/20385676

2. Jordan P, Van Rooyen D, Venter D. Endotracheal tube cuff pressure management in adult critical care units. S Afr J Crit Care [Internet]. 2012[cited 2016 Jun 30];28(1):13-6. Available from: http://www.sajcc.org.za/index.php/SAJCC/article/view/129/148

3. Abbasi S, Mahjobipoor H, Kashef P, Massumi G, Aghadavoudi O, Farajzadegan Z, et al. The effect of lidocaine on reducing the tracheal mucosal damage following tracheal intubation. J Res Med Sci[Internet]. 2013[cited 2016 Mar 30]:18(9):733-8. Available from: https://www.ncbi.nlm.nih.gov/pmc/articles/PMC3872578/

4. Godoy ACF, Vieira RJ, Capitani EM. Endotracheal tube cuff pressure alteration after changes in position in patients under mechanical ventilation. J Bras Pneumol[Internet]. 2008[cited 2016 Mar 30];34(5):294-7. Available from: http://www.scielo.br/pdf/ jbpneu/v34n5/en_v34n5a08.pdf

5. D'Aragon F, Beaudet N, Gagnon V, Martin R, Sansoucy Y. The effects of lidocaine spray and intracuff alkalinized lidocaine on the occurrence of cough at extubation: a double-blind randomized controlled trial. Can J Anaesth[Internet]. 2013 [cited 2015 Oct 21];60(4):370-6. Available from: https://dx.doi.org/DOI 10.1007/s12630-013-9896-8

6. Barbas CS, Ísola AM, Farias AM, Cavalcanti AB, Gama Am, Duarte AC, et al. Brazilian recommendations of mechanical ventilation 2013. Rev Bras Ter Intens[Internet]. 2014[cited 2015 Nov 30];26(2):89-121. Available from: https://dx.doi. org/10.5935/0103-507X.20140017

7. Sole ML, Su X, Talbert S, Penoyer DA, Kalita S, Jimenez E, et al. Evaluation of an intervention to maintain endotracheal tube cuf pressure within therapeutic range. Am J Crit Care[Internet]. 2011[cited 2016 Oct 15];20(2):109-17. Available from: https://dx.doi. org/10.4037/ajcc2011661

8. Sole ML, Penoyer DA, Su X, Jimenez E, Kalita SJ, Poalillo E, et al. Assessment of endotracheal cuff pressures by continuous monitoring: a pilot study. Am J Crit Care [Internet]. 2009[cited 2016 Oct 15];18(2):133-43. Available from: https://dx.doi. org/10.4037/ajcc2009441

9. Lizy C, Swinnwn W, Labeau S, Poelaert J, Vogelaers D, Vandewoude K, et al. Cuff pressure of endotracheal tubes after changes in body position in critically ill patients treated with mechanical ventilation. Am J Crit Care[Internet]. 2014 [cited 2015 Nov 30];23(1):e18. Available from: https://dx.doi.org/10.4037/ajcc2014489

10. Royal College of Anaesthesia Audit Compendium. Critical care services. In: Nightingale P, Griffiths H, Clayton JA, (Eds.). Section 10.3. Tracheal tube cuff pressures[Internet]. 2016 [cited 2016 Oct 15]. https://www.rcoa.ac.uk/system/files/CSQ-ARB-Contents intro.pdf

11. Diretrizes Brasileiras de Ventilação Mecânica. Ventilação Mecânica AMIB e SBPT. Versão eletrônica oficial [Internet]. AMIB e SBPT; 2013 [cited 2016 Oct 10]. Available from: http://itarget.com.br/newclients/sbpt.org.br/2011/downloads/arquivos/Dir VM 2013/Diretrizes VM2013 SBPT AMIB.pdf

12. Arts MP, Rettig TCD, Vries J, Wolfs JFC, Veld BAI. Maintaining endotracheal tube cuff pressure at $20 \mathrm{~mm} H \mathrm{Hg}$ to prevent dysphagia after anterior cervical spine surgery; protocol of a double-blind randomized controlled trial. BMC Musculoskeletal Disord [Internet] 2013[cited 2016 May 18];14:280-1. Available from: http://www.biomedcentral.com/1471-2474/14/280

13. Sole ML, Penoyer DA, Su X, Jimenez E, Kalita SJ, Poalillo E, et al. Assessment of endotracheal cuff pressure by continuous monitoring: a pilot study. Am J Crit Care [Internet]. 2009[cited 2015 Nov 30];18(2):133-43. Available from: http://ajcc.aacnjournals. org/content/18/2/133.long

14. Liu J, Zhang X, Gong W, Li S, Wang F, Fu S, et al. Correlations between controlled endotracheal tube cuff pressure and postprocedural complications: a multicenter study. Anesth Analg [Internet]. 2010 [cited 2015 Nov 30];111(5):1133-7. Available from: https://www.ncbi.nlm.nih.gov/pubmed/20736432

15. Cerqueira NB, Albuquerque CG, Souza VV, Ramos FF, Andrade FMD, Correia Junior MAV. Fatores que alteram a pressão dos balonetes internos de tubos endotraqueais e a necessidade de sua monitorização. ASSOBRAFIR Ciênc [Internet] 2011 [cited 2016 Apr 12];2(1):29-38. Available from: http://www.uel.br/revistas/uel/index.php/rebrafis/article/download/7905/7717

16. Penitenti RM, Vilches JIG, Oliveira JSC, Mizohata MGG, Correa DI, Alonso TRMB, et al. Controle da pressão do cuff na unidade terapia intensiva: efeitos do treinamento. Rev Bras Ter Intens [Internet] 2010 [cited 2016 Apr 14];22(2):192-5. Available from: http://www.scielo.br/pdf/rbti/v22n2/a14v22n2.pdf 